\title{
Linkage of Municipal Solid Waste Management and Peacebuilding: A Case Study in Northern Jordan Affected by Syrian Refugee Influx
}

\author{
Tsuyoshi Yamamoto
}

\begin{abstract}
Refugee crisis has become an increasing global issue, particularly in the Middle East in areas where there has been a great influx of Syrian refugees since 2011. One of Syria's neighboring countries, Jordan, has faced various challenges due to the increasing residents in the municipal area, which has led to the decline in levels of public services, such as water and electricity supply, and waste and wastewater management. This study sought to appreciate links and implications of the improvement of municipal solid waste management to contribute to peacebuilding in refugee host communities, with a case study in Northern Jordan. The study was conducted through two semi-structured field surveys and grey literature reviews, and results indicated that community based activities at the waste collection stage have the potential to promote social cohesion and support peacebuilding in conflict-affected countries.
\end{abstract}

Index Terms-Host community support, resilience, social cohesion.

\section{INTRODUCTION}

Jordan has been affected greatly by the conflicts in Syria, particularly due to the massive influxes of Syrian refugees. The estimated number of Syrians in Jordan is 1.3 million, half of whom are Office of the United Nations High Commissioner for Refugees (UNHCR) registered refugees [1]. UNHCR notes that Jordan continues to host a largest number of refugees relative to its national population, where one in three citizens is considered as a refugee [2].

This crisis has been disturbing Jordan's GDP growth, as refugee-related costs has been an economic and social burden and preventing fiscal consolidation [1]. There are voices of stress from the host communities, particularly from the socially vulnerable Jordanians [1]. Rising social tensions have the potential to cause secondary conflict in refugee hosting communities [3]. On the other hand, refugee influx has also been providing opportunities to leverage international support, and there are literature indicating refugee influx as the main reason of resource mobilization to implement its national development projects [4].

Donor countries have been using Official Development Assistance (ODA) to cover the costs of hosting refugees surged by 27.5 percent to US $\$ 15.4$ billion between 2015 and 2016, which is approximately 10.8 percent of the global ODA [5]. In Jordan, the estimated cost of hosting refugees was US\$2.9 billion in 2015, but, for 2016, Jordan received

Manuscript received July 15, 2018; revised December 1, 2018

Tsuyoshi Yamamoto is with Japan International Cooperation Agency (JICA), Tokyo, Japan (e-mail: Yamamoto.Tsuyoshi@jica.go.jp). about 60 percent of the funding required under the Jordan Response Plan (JRP) [1].

In the context of peacebuilding, studies and researches prior to 2016 defined peacebuilding as post-conflict activity according to the UN resolutions [6]-[9], however, UN resolutions in 2016 have extended the concept of peacebuilding to a more holistic approach including processes and activities before, during and after the conflict [10], [11].

Discussions on the linkage between environment and conflict has been present since the 1990s: 'The 1990s saw a growing concern that at least some of these conflicts may be linked to environmental issues' [12]. Historically, natural resource management has been the main focus in the sector of environment and peacebuilding, because many conflict-affected countries fundamentally depend on their natural resources to build resilience to prevent the arise of new conflict and further environmental degradation [13]-[15].

United Nations Environment Programme (UNEP) illustrated that building solutions to environmental issues could also serve as an effective platform and catalyst for enhancing dialogue and building relationship in conflict affected countries. UNEP also pointed out that development assistance on the environment can promote peacebuilding through building trust in communities, which will contribute to reconciliation [16], [17]. Moreover, the transition from hostility to hospitality in host communities is assumed as prerequisite of social cohesion, and to provide means of achievement through environmental dimensions may provide new pathways to achieving the SDGs: 'Leave no one behind' [18].

Despite past studies focused on natural resource management, this study has focused on waste management, and its linkage to peacebuilding, as production and disposal is a common and inevitable problem in human daily life, however the linkage of the two is not sufficiently discussed in past literature. To prevent local conflict and foster social cohesion in host communities, participatory waste management system based on community-based approach is effective, and its mechanism brings a new perspective which is an uncovered study area in previous conflict and development studies [19], [20].

Waste management is one of the most critical and high-needs development issues in Jordanian municipalities [21]. Moreover, waste management, for example the Cash-for-Work approach, leads to a perspective where environmental factors have the potential to contribute to alleviating local tensions in host communities, and promoting 
social cohesion between local residents and the refugees [21].

For the reasons discussed above, municipal solid waste management acts as a gateway to have insights from a variety of perspectives in host communities, and this study seeks to appreciate links and implications of the improvement of municipal solid waste management and peacebuilding.

\section{Methods AND MATERIALS}

A qualitative methodology was adopted for this study, because quantitative study was difficult due to unavailability of data on both waste management and peacebuilding. The quantification on behavior change on tension and cohesion in host communities was challenging because social cohesion remains a sensitive and political issue in host communities. Issues of integration of refugees and host communities must be considered from legal, economic and social dimensions, which cannot be quantified.

Methods included literature reviews, as well as two field surveys: "Data Collection Survey on Waste Management in Northern Region accepting Syrian Refugees in the Hashemite kingdom of Jordan", a JICA survey in 2016, and "Preparatory Survey Report on the Project for Improvement of Waste Management Equipment in Northern Region hosting Syrian Refugees in the Hashemite Kingdom of Jordan", a JICA survey in 2017. The survey team was consisted of the Global Environment Department of JICA and the Kokusai Kogyo Co., Ltd. [22].

JICA Surveys were conducted through data collection work in the field and carried-out through interviews and discussions with relevant stakeholders in charge of municipal solid waste management, mainly public organizations named Joint Service Councils (JSCs). The purpose of these JICA surveys were to investigate the needs for improving the existing waste management equipment and facility in northern region of Jordan which has the main region hosting Syrian refugees, in order to improve the local environment and sanitation, and the living condition for host communities [22].

In addition to the above-mentioned surveys, the JICA survey team referred to two reports produced by the government of Jordan as national master plans in waste management sector. The two documents were as follows: "Regional Municipal Solid Waste Management Plan for the Northern Region of Jordan", 2017 supported by the GIZ, and "Regional Municipal Solid Waste Management Plan for the Central Region of Jordan”, 2017 supported by the European Union. The master plans were finalized through discussions with international donors, Ministry of Municipal Affairs of Jordan (MoMA) and relevant international donors, then compiled the JICA survey report.

Furthermore, this study referred the JRP: a three-year vision and the first nationally led comprehensive national plan for refugee and development responses. The JRP was developed by the Jordan Response Platform for the Syria Crisis, which is in line with the aid coordination principles of the Busan Partnership for Effective Development Co-operation (2011) [23]. Improvement of municipal solid waste management, the main issue of this study, was categorized within the local governance and municipal services in the JRP [24].

JICA survey team deeply discussed with the United Nations Development Programme (UNDP), whom was also one of major donors in waste management sector in Jordan along with JICA, implementing the project: "Improving Solid Waste Management and Income Creation in Host Communities". The main component of the project was the establishment of the first sanitary cell in northern Jordan, which has the second largest landfill in the country aligned with the international standards for solid waste cell lining, leachate collection system and biogas collection system [25].

\section{STUdy AREA}

The study took place in the northern area of Jordan because the largest number of refugees was settled in this area, in particular in Amman governorate (196,487 refugees), Mafraq governorate (163,384 refugees) and Irbid governorate (140,246 refugees) as indicated in Figure one [26]. Therefore, many international donors implemented support projects in northern region.

According to the data portal operated by UNHCR, the total persons of concern and total number of Syrian refugees in Jordan as of $24^{\text {th }}$ September 2018 was 671,428 individuals: 545,786 of them living in urban settings. In other words, more than $80 \%$ of these Syrian refugees were scattered within the local host community [26].

The main border gate between Jordan and Syria was located in the northern part of Jordan. Therefore, many refugees residing in Jordan has come from the southern part of Syria. The place of origin of Syrian refugees was Dara (40.9\%) and Homs (15.8\%) [27].

There were three Syrian refugee camps in Jordan with a total number of 126,490 refugees, all of them located in northern Jordan: 78,554 refugees in the Zaatari camp, 41,089 refugees in Azraq, 6,847 refugees in EJ camp [27]. The waste generation rate of these camps was reported to be 0.64 $\mathrm{kg} / \mathrm{capita} /$ day in average [22]. In the Zaatari camp, more than half of refugees are children, and the size of the camp is almost fourth biggest city in Jordan [28].

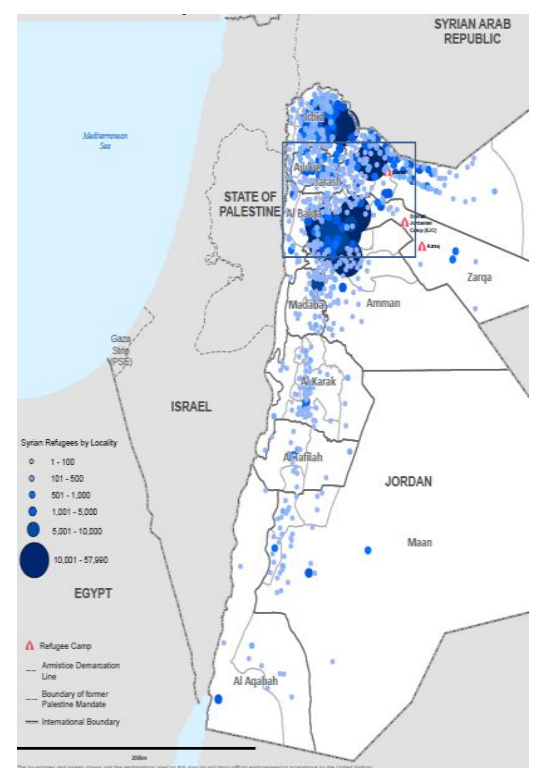

Fig. 1. Syrian refugees in Jordan as of March, 2018 [29]. 
Final disposal site is one of the most important issues in waste management. Al-Ekeider Landfill, which is the only sanitary system and is the main landfill located in the border zone between Jordan and Syria. There is only sanitary landfill in a region is common situation in middle-income countries according to the report by the World Bank [30]. The Canadian government and the UNDP implemented a project for expanding the services of the landfill to enhance its capacity to take on the increased volume of municipal solid waste caused by the influx of Syrian refugees [31]. Municipal solid waste from Irbid, Ajloun and Jerash, and a part of Mafraq governorate is disposed in this landfill. The second biggest landfill in the northern region is Al-Huseyneyat Landfill, which is located next to the Zaatari camp [22].

\section{RESULTS AND DISCUSSION}

\section{A. Literature Review}

Past literature revealed the trends and gaps on interaction between municipal solid waste management and peacebuilding, from two important points.

Firstly, the Cash-for-Work, implemented by a few NGOs in Jordan, was pilot activities on recycling aiming at creating jobs for refugees through municipal solid waste management, in refugee hosting communities and refugee camps. The following pilot project studies illustrated good examples of contribution to peacebuilding through the Cash-for-Work scheme.

Oxfam, an international NGO attempted to establish a recycling model in the Zaatari refugee camp and promoted the implementation of waste collecting, sorting and processing process across the camp as a pilot project. As part of the project, Oxfam collaborated with Syrian refugees and the Jordanian host community, and achieved a $20 \%$ reduction of waste in volume [32]. In addition, another international NGO, Disaster Waste Recovery pointed out that Cash-for-Work project in the waste management sector contributed to mitigating tensions and fostering social cohesion in host communities. Disaster Waste Recovery stated that there was a reduction in tension between Syrians and Jordanians, both within their waste collection groups, as well as between groups [33].

The Cash-for-Work scheme has provided important support for vulnerable people in terms of peacebuilding in disaster-affected countries as well [34]. One research reviewed the potential of recycling of materials such as plastics, paper and cardboard; these materials have significant potential to be separated and collected for recycling purposes in local commercial base [35]. A UNDP study reported that the application of the Cash-for-Work scheme in the process of picking-up, sorting and reusing/recycling municipal solid waste was effective for stabilizing livelihoods [34].

There were also cases providing cash compensation, and creating new jobs. For example, after the earthquake hit Nepal in 2015, the UNDP conducted a debris removal and disposal project as a mean of income generation [36]. There are increasing numbers of natural disasters, which are imposing significant negative effects in particularly in vulnerable nations. Mercy Corps examined debris removal as Cash-for-Work in the tsunami-affected countries such as Indonesia and Sri Lanka because the first priorities of those communities were to clear away the debris [37].

UNDP produced a guidance note on municipal solid waste management for mid-crisis and post-crisis settings. The guidance note provided a practical manual for municipal solid waste management, intended to contribute to post-crisis livelihood stabilization, and the strengthening of the service delivery of local governments towards fostering the relationship between the government and society [34]. There are also guidelines produced by the United Nations Office for the Coordination of Humanitarian Affairs (OCHA) and UNEP targeting waste generated not only by earthquakes but also by typhoons and tsunamis [38].

The case of Libyan conflict provided a good example of the importance of ensuring legal regulations and recycling of construction waste [39]. Issue of construction waste is very common in post-conflict countries, especially after heavy civil wars, thus the design and implementation of post-crisis debris management is important issue. Debris management is a part of peacebuilding process because re-building infrastructure is not until debris removal. This approach has possibility to utilize for improvement of municipal solid waste management.

Various literature suggested the Cash-for-Work approach does not possess an institutionalization mechanism, as it relies on donor funds aimed for temporary job creation. However, appropriate waste management is built upon a permanent system, thus there is a need to establish a seamless mechanism to integrate the current Cash-for-Work approach into the permanent waste management system. The involvement of local authorities and public and private entities at the policy level is critical to build successful municipal solid waste management system which will consequently contribute to the peacebuilding process in host communities [40], [41].

Secondly, there were few past studies and literature that suggested the importance of peacebuilding for building relationships and making engagement among refugees, host communities and local government.

For example, the UN and World Bank stated that civil society plays a key role in development of social unity and joint action for peace by building relationships in daily interactions. One of daily interactions is waste collection and recycling which were focused on this study. Even though states hold the principal obligation for prevention of conflict, civil society, the private sector, regional organizations and international societies must be involved to create a resilient and peaceful society [5].

Joint research of the UN and World Bank brought an insight on a common framework of waste collection with multi-stakeholders: that it prevents conflict in host community and strengthens social and civic ties. The reason of importance of waste management is because waste-related issues is a reflection of the state of the society, as they reflect various factors-including economic, historical and cultural conditions and change of the country, city or region [42].

The British Embassy in Amman published a research report, which concluded that challenges to social cohesion 
emerged at two levels: 1 . tensions between host communities and refugees, and 2. inadequate communication between residents and the local government. In addition, the assessment of research report identified solid waste management was one of three key sectors which have been most affected by the large influx of refugees. One finding from this research was that the livelihood sector such as employment and housing was the major sector where Jordanians and Syrians with high tension [43], which reflects the importance of the second point made by the above report: multi-dimensional capacity development and engagement of local government is essential at the peacebuilding stage.

The role of each stakeholder in municipal solid waste management is correlation and every stakeholder including informal sector is required to play its role, independently or in cooperation with one another. Waste management flow, which includes the process from waste generation through to collection and intermediate treatment and final disposal, involved multi-stakeholders in all stages of the process [44].

Another paper introduced the concept of peacebuilding as change of individuals, relationships, cultural patterns, and structures to move away from harming human security [45]. Sharing information about goals, activities and outcomes of activities was important for peacebuilding [45]. These factors are key principals not only in peacebuilding, but also for effective municipal solid waste management.

One of the findings from a research on asylum seekers in the U.K. was the importance of action and political leadership of the residents themselves in challenging social inequality, injustice and prejudices that were frequently based on misinformation for migrants. This research provided the importance of media because it raised public anxiety and misperceptions mirrors increased numbers of media articles about asylum, and political tensions over immigration [46].

Through the above literature review, the gaps and trends in knowledge on peacebuilding and waste management became clear, and that participatory approach in waste collection and separation for promotion of recycling based on that finding has a possibility to promote mix of different attribution such as Syrians and Jordanians [47], [48]. Moreover, it build new interpersonal relationships as a neighbor and member of community. This new perspective will be examined further in the following section $D$. Linkage of waste management and peacebuilding based on the facts and findings, which were illustrated in the next section B., and C.

\section{B. Waste Management in Jordan}

Waste management is a common issue amongst all human beings, including vulnerable people such as refugees, as all human activities lead to production and consumption of physical materials [30], [44]. Nobody can stop waste production entirely, but every stakeholders can make a contribution through participation in waste management process. Waste management has been a serious environmental and social concern in Jordan even before the refugee influx, particularly in the major cities as a result of rapid urbanization, due to increased levels of waste generation and lack of appropriate land and facility for final disposal [49].
Economic growth and internal migration to urban areas are linked to increases in per capita generation of waste [30]. According to the Work Bank report, the generation of waste in the Middle East and North Africa region is expected to double by 2050 , and generated waste at an average of 0.81 kilogram per capita daily as same as Jordan's average currently. This is higher than global average 0.74 [30]. Rapid population increase and urbanization lead to a new megacity, making waste collection and procuring waste treatment site and final disposal site extremely difficult [30]. Reducing the volume of municipal solid waste through recycling and reuse is a common approach, thus the idea of this study can contribute reduction of waste for establishment of sustainable waste management system.

In Jordan, there are two main ministries implementing policies and regulations on waste management. MoMA is in charge of the regulations and management of non-hazardous waste including municipal solid waste, and the Ministry of Environment is responsible for developing policy, planning and monitoring the management of hazardous waste. Furthermore, municipalities are responsible for the cleaning, collection and transfer of waste, which can be conducted by the municipalities themselves or JSCs as contractors [22]. There are 100 local municipalities, 21 JSCs and 18 official disposal sites: four are located in the northern region and five are located in the central region [50]. However, one of findings thorough the JICA surveys is that the central and local government authorities lack the financial capacity to provide JSCs with necessary equipment, and the waste management sector is not placed as the top priority in budget allocation from central government.

The National Solid Waste Management Strategy sets 11 policies in total, and two of them are relevant to the refugee issue: Policy 1 responds to the emergency municipal solid waste management needs of Jordanian societies, resulting from the increased influx of refugees from the neighboring countries; and Policy 5 notes the mitigation of informal waste-picking of municipal solid waste through integration of informal sector into the municipal solid waste management system [22]. Currently, finance is the largest bottleneck upon implementing the above policies in JSCs, because municipal solid waste management itself is not considered as capital goods. According a report from World Bank, municipal solid waste management is a large expense: more than 10 percent of municipal budgets in middle-income countries [30].

The JICA survey team investigated the flow of municipal solid waste of 62 municipalities and three Syrian refugee camps in six governorates of the survey area, through consultations with JSCs [22]. The consultations revealed that JSCs were the only agency that has experience and knowledge on municipal solid waste management services, and MoMA had limited knowledge and experience, despite them being the lead agency of implementing waste management policies.

According to the statistics demonstrated in Figure 2 by United Nations Department of Economic and Social Affairs (UN DESA) [51], increasing urbanization in Jordan is proportionate to the increase the challenges in meeting the needs of the growing urban populations, including 
appropriate waste management, employment and other BHN.

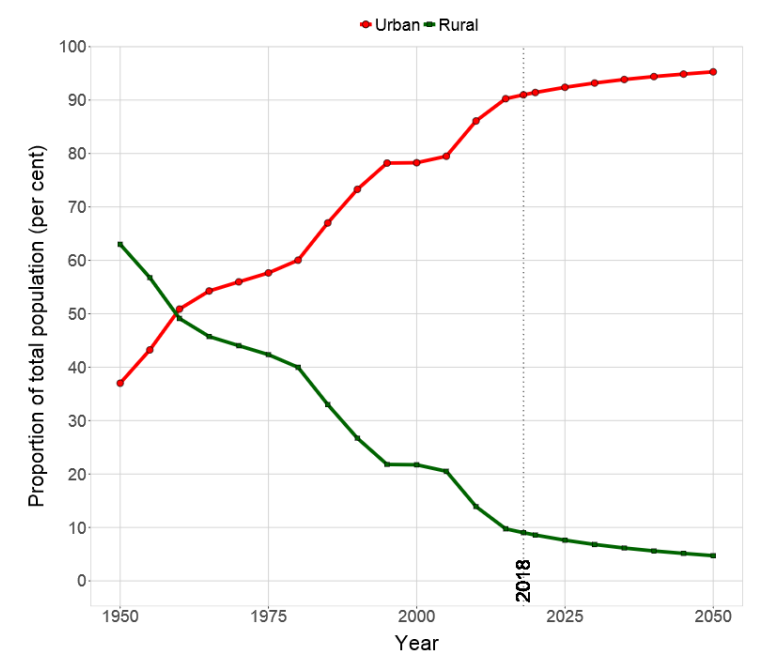

Fig. 2. Percentage of population in urban and rural areas in Jordan [51].

According to the national census in $2015,30.6 \%$ of the total population in Jordan were non-Jordanians: the majority mostly being Syrian refugees, and the remaining were refugees from Palestine and Iraq. Waste management services for Palestinian refugee camps are operated by the United Nations Relief and Works Agency for Palestine Refugees in the Near East (UNRWA). Operations in refugee camps include waste collection and transportation system operated by UNRWA vehicles and staff, and landfill disposal operated by JSCs. This system, established by the UNRWA, provides work opportunities for Palestinian refugees, however there are arguments on operational efficiency, cost efficiency, and social cohesion because these waste collection and transportation systems are entirely different from the Jordanian system operated by JSCs [22].

Despite increasing issues in the Middle East such as the Syrian crisis, urbanization including the rapid population influx from rural areas will continue to raise further challenges in the waste management system for Jordan. Improvement of waste management will support cities become more resilient to disasters as well [30]. To cope with the rapid changes, it will become increasingly important for municipalities to increase social resilience through host community support in the future.

Through the above section, the background and facts of this study became clear for further examination in the Section D., and that reinforcing a new perspective, which this study has indicated that specific attention must be payed to vulnerable groups including refugees, asylum-seekers and migrants.

\section{Impact of Refugee Influx on Waste Management}

As described in the previous sections A and B, the increase in population is proportionate to the increase in solid waste. In Mafraq, the northern governorates of Jordan, the population has more than doubled since 2011, leading to bottlenecks in the provision of public services. The influx of Syrians and increasing population stresses host-community capacities, Syrians have cast a light on major contemporary challenges of Jordanian society [4]. Thorough the JICA surveys, it became clear that the difficulty to preserve appropriate waste management systems, and necessary levels of public hygiene.

According to the UNDP study on municipal needs assessment published in 2013, solid waste management had been the top priority in 33 amongst the 36 municipalities in the northern region, due to rapid increase of waste and aging infrastructure. This study also specified that equipment and financial support was required in these municipalities [8].

There are various studies by Jordanian researchers and international donors that indicate increasing burdens of waste management service due to the Syrian refugee influx. For example, Abu Qdais et al. notes that the volume of waste disposed in Greater Irbid Municipality increased from 500-600 ton/day in 2005 to 1,100-1,200ton/day in 2016 [52].

The JRP 2018-2020 indicated that solid waste in the municipalities increased by 11\%: $85 \%$ of which was attributable to the refugee influx. The amount of waste that exceeded the landfill capacity also rose by $19 \%$ : $91 \%$ of this was attributable to the influx. The gap between the landfill capacity and the total waste volume was 812 ton and 886 ton per day in the North and Middle region, respectively [24]. Increased waste accumulation has caused an increase in pests [30]. Moreover, the JRP 2018-2020 stated that the refugee influx has particularly affected waste management collection, transportation and disposal in the local governance and municipal services. The JRP 2018-2020 also mentioned that refugee influx further exacerbates municipal services, which are currently not functioning well [24].

The JRP pointed out that solid waste management was one of the main challenges faced by Jordanians and Syrians in host communities due to inefficient usage and lack of maintenance of waste collection vehicles and as well as the limited capacity of landfills. There is evidence that $56 \%$ of surveyed households indicated that service delivery was insufficient to meet the increasing demand. Moreover, the JRP suggested that improvement in public services would contribute to improving social cohesion [24].

The increase of population and expansion of residential areas were proportionate to the expansion of the garbage collection zone because Syria were scattered within existing communities. It became necessary to improve the efficiency of collection and transport operations, for example by setting up waste transfer stations for waste transfer from small- or medium-sized garbage trucks to larger trucks. The cost of collection and transport accounts for a high percentage of the total cost, however as previously mentioned, financial services in Jordan in the waste management area is limited. Improving the efficiency of waste collection and transport systems leads to cost reduction, therefore, the government of Japan has provided equipment for transfer stations based on the result of JICA survey, to achieve service efficiency of waste collection [22].

However, current JSCs in Jordan have limited capacity to establish and/or organize the operation and maintenance system partially [22]. Therefore, international donors have been providing equipment and capacity development of JSCs [24]. The JICA project aims to provide host community support, and has been strengthening waste management capacity to improve the sanitation and the living environment 
in the northern part of Jordan where there are the most number of refugees. The project supported the provision of equipment such as hoppers and compactors for transfer stations and final disposal sites that have inadequate treatment capacity [53].

Recent support from international donors has been focusing more on host communities that were severely affected by the refugee influx. In order to overcome this challenge, the Government of Jordan established a strategic partnership mechanism that combines existing refugee support, resilience-strengthening and development assistance to Syrian Refugees [22]. The municipal solid waste management service of three Syrian refugee camps is provided by NGOs through the Water, Sanitation and Hygiene (WASH) program by UNICEF. In Zaatari refugee camp, there is a composition analysis, and its result showed that the composition percentage in Zaatari Camp was similar to that in municipalities in Jordan [35]. Its composition result presented the organic waste is $53 \%$, while plastics, textile, and paper and cardboard are $12.85 \%, 10.22 \%$ and $9 \%$, respectively, and plastics, paper and cardboard have huge potential to be separated and collected for recycling purposes on market base [35].

In addition, hazardous waste is categorized in the environment sector in the JRP, because it poses threats to public health and the environment. The amount of hazardous waste generated in 2015 was estimated to be 45,000 ton/year. This includes pharmaceutical waste, which has increased from 1,731.68 m3/year in 2011 to 2,500 m3/year in 2016 . Hence, considerable rehabilitation or expansion of the final disposal sites for hazardous waste in Jordan was necessary. This situation suggests that the influx of Syrian refugees has generated adverse environmental effects on Jordan. The treatment of hazardous waste faced similar challenges with municipal solid waste such as lack of human capacity, equipment, and monitoring programs [24].

Through the above section, the challenges in refugees hosting communities became clear, and that shedding light on new insights, and these discussions were deepened in the following section.

\section{Linkage of Waste Management and Peacebuilding}

Social cohesion is a common term in immigration and conflict prevention [54]. There has been little effort to integrate refugees into the community in many parts of the world, leading to social division and animosity. To overcome such situation, participatory waste management on a community basis has the possibility to involve informal groups including refugees, which will consequently lead to the increase in the number of residents involved in waste collection, and the improvement of the capacity of JSCs.

Participation of all relevant stakeholders is the key for participatory waste management [55], thus it would be an empowerment process for marginalized people such as Syrian refugees. In the design and implementation stage of participatory waste management, it is important to collect opinions from host communities and refugees, but also to share goals, activities and outcomes with the relevant participants. The fact that marginalized people is included in this process can lead to an idea that participatory waste management has the possibility to be a tool for social inclusion. Within the various stages of waste management, it is particularly effective to conduct recycling on a community basis, in terms of financial and environmental cost.

Disaster Waste Recovery stated that upon target selection, it is critical to consider both gender and vulnerability for gender mainstreaming. Their targets of the Cash-for-Work programs were waste management groups, consisting of $50 \%$ women and 3\% disabled people. Hiring approaches can be either top-down (institutional approach) and or bottom-up (grass-roots approach), but the participative approach is considered as the latter, allowing better coverage and inclusion of women than top-down approaches [33].

Policy 8 of National Solid Waste Management Strategy states the importance of public motivation, and that increasing public awareness and education will increase the participation of the public in safe municipal solid waste management practices [22]. This study revealed that at present, waste collection and sorting are mainly conducted by Egyptians thus safe and hearth issues of waste management workers is not considered as a priority within the Jordanian government. However, this lack of public awareness is leading to the lack of improvement of unsafe working environment of waste collectors in final disposal sites, which is a significant issue from also from a global perspective. Additionally, child labor issue is a common challenge in peacebuilding, because many refugees facing poverty [40]. In Jordan, children in school age is considered as important labor forces in refugee families, and many Syrian children are currently working as waste pickers [56].

Additionally, the Cash-for-Work scheme also contributes to mitigating tensions and improving social cohesion in host community, as coordination and cooperation for efficient waste separation and collection in community base have a great potential to build personal relationship and decrease tensions in the community as above examined. In particular, Jordan and Syria has had a historical relationship prior to the Syrian crisis, built on a sense of hospitality and compassion, thus the above approach is expected to have substantial impact if successful [57].

According to a survey of Jordan public opinion in 2015, $76 \%$ of the respondents answered that the quality of municipal services, waste collection in particular, has been negatively affected by the Syrian refugee influx. This percentage was nearly equivalent to the quality of health services in public clinics and hospitals (79\%), and the quality of education in public schools $(75 \%)$, which have historically been the two main issues of national development [58]. Considering the current situation in Syria, many refugees are expected to continue residing in Jordan, thus there are increasing efforts to reduce hostility and tension between the refugees and the host community. Major role of international donors is critical to reduce this negative impact by refugees, as providing assistance to improve waste collection in the host community will significantly increase public satisfaction according to the above public survey.

According to the report from the World Bank, many informal waste pickers remain with unhealthy conditions and a lack of social security. Support for these informal waste pickers can lead to more job opportunities in the recycling 
sector and reduction of poverty. The World Bank also pointed out that formalizing and integrating waste pickers into the economy and society accelerate achieving the SDGs in future [30]. However, findings from the survey revealed that there are reasons people prefer to keep these processes informal, as they are afraid to disclose personal information to the Syrian government. Hence, still many Syrians choose not to be registered to the UNHCR as refugee and continue to live in Jordan [59].

The JRP 2018-2020 reports that 15,000 beneficiaries are expected to engage in Cash-for-Work for municipal waste management, land management and infrastructure projects, including in the refugee camps [24]. As above described, the Cash-for-Work contributing to create economic opportunities for Jordanians in host communities and Syrian refugees, and promoting mutual exchange and understanding in each other through municipal solid waste management services.

Development projects in the local governance and municipal services sector of the JRP target not only improvements of service delivery performance such as municipal solid waste management, but also social cohesion. The plan also suggests that short-term interventions in the waste management sector shall focus on social cohesion and waste collection, and, medium-term interventions would focus on landfills [24].

In municipal solid waste management, local residents are classified as beneficiaries of waste disposal services, but they also have responsibilities as waste dischargers. In other words, when discussing waste management problems, it is necessary to consider both sides of the responsibilities of the citizens: as beneficiaries and polluters. In order to fulfil both of these responsibilities, particularly at the stage of waste collection and storage, it is important for local residents need to cooperate with JSCs and collecting companies; however, it remains a challenge to practice this as a community. To implement smooth management, sharing information about goals, activities and outcomes in peacebuilding is also considered important for effective municipal solid waste management [45].

Communities with refugees consist of people from diverse nationalities and cultures, thus it is difficult at times for everyone to comply with fixed norms and regulations without guidance or administration to promote recycling. This is particularly challenging for informal groups, such as refugees and illegal immigrants without citizenships, as the cultural and societal ties between communities and refugees are weak.

Appropriate waste management can be an effective strategy to overcome this challenge of currently fragmented communities, and to build a societal network. Participation of socially vulnerable groups in municipal solid waste management could build an inclusive system, and the process for improvement of waste management could be recognized as the process of society building for the industry and the public to unite and seek coexistence with others.

In order to build a stable and resilient society against various societal and environmental changes including refugee influx, this study revealed the importance of consulting with all relevant stakeholders to identify and implement community priorities and build trust in the central and local governments. To ensure that the benefits of stable and resilient society are inclusive to all persons concerned, policies and regulations to manage public services, which focuses on the needs of vulnerable groups such as refugees is a vital component that needs to be taken into account in government development priorities.

In future studies, to demonstrate effectiveness of waste management in the peacebuilding process and mitigating social tensions and fostering social cohesion, it would necessary to conduct more in-depth interviews with refugees and host communities to deliver evidence on awareness and behavior change. This study did not provide sufficient data to make comparisons between groups whom are hosting refugees and those that not. This is because social cohesion of Syrian refugees remains a sensitive topic in both political and social dimensions. Contrary to the Jordanian popular perception, the presence of Syrian refugees in Jordan can benefit the country by bringing in much needed resources and development projects by international donors. Public opinion is constantly changing in conflict-affected countries due to vulnerability and fragility.

\section{CONCLUSION}

This study has suggested that there is possibility that improvement of municipal solid waste management will contribute to peacebuilding in refugee-hosting countries. However, limitation of the study methods was the quantification on behavior change toward mitigating social tensions and fostering social cohesion, because social dimensions of municipal solid waste management were multi-level. Moreover, social cohesion remains a sensitive and political issue in Jordan. It is not easy to make decisions for many Syrian peoples whether return to Syria or not due to current complicated situation.

According to the UNHCR, 68.5 million people were forcibly displaced worldwide as a result of persecution, conflict, violence, or human rights violations in 2017 [2]. Refugee influx is an on-going challenging and complex issue in every country, and further research and study are needed. There are many neighboring countries and host communities which believe that the settlement of refugees in their countries increase the possibility of terrorism, deprivation of existing jobs and social welfare services in host communities.

International Organization for Migration (IOM) also provides an overview of global data on migrants that there are 244 million international migrants, which is equal to $3.3 \%$ of the world's population [60]. Globalization is not just a matter of economic development: it is must also be considered from the perspective of the flow of human beings, capital, goods and services in the world. Migration has grown into one of the major reasons of urbanization, and the need to build social cohesion and resilience in local communities will be common challenge in major urban cities.

This study has brought new perspectives and means for achieving the SDGs, with a unique combination of environmental, social and political dimensions. Under these global goals, international communities must act together, and sometimes consider entry points and strategies that can 
seem out-of-the box to build ways of achieving a society which is truly "Leaving no one behind", including refugees and other vulnerable people that are in the bottom of the pyramid. The international community, as a whole, needs to engage with states and host communities to promote the inclusion of refugees and other vulnerable people in public service such as municipal solid waste management system.

The views expressed in this paper are those of the author and do not necessarily represent the official positions of JICA.

\section{ACKNOWLEDGMENT}

The author is greatly acknowledging the implementation for the above-mentioned JICA survey composed of Global Environment Department of JICA and Kokusai Kogyo Co., Ltd.

An earlier version of this paper was presented at the 28th Annual Conference of the Japan Society for International Development. The author acknowledges comments and suggestions received from the conference participants.

The author also thanks anonymous reviewers whose comments greatly improved the paper manuscript.

\section{REFERENCES}

[1] IMF, Jordan: 2017 Article IV Consultation-Press Release; Staff Report; and Statement by the Executive Director for Jordan, Country Report No. 17/231, July 24, 2017.

[2] UNHCR, Global Trends 2017, 2018

[3] World Vision, Social Cohesion between Syrian Refugees and Urban Host Communities in Lebanon and Jordan, 2015.

[4] F. Alexandra, Jordan's Refugee Crisis, 2015.

[5] United Nations, World Bank, Pathways for Peace: Inclusive Approaches to Preventing Violent Conflict, 2018.

[6] B. Michael et al., Peacebuilding: What Is in a Name? 2007, pp. 35-58.

[7] JICA, Thematic Guidelines on Peacebuilding, 2011.

[8] E. Sharon and H. Caroline, Refugees and Peacebuilding Refugees and Peacebuilding: Poor Country Problems in Cambodia and Bosnia-Herzegovina, Practical Approaches to Peacebuilding: Putting Theory to Work, Lynne Rienner Publishers, 2016.

[9] The article of Adrian Martin adopted a theoretical approach to the environment-conflict nexus in areas hosting refugees, Environmental Conflict between Refugee and Host Communities, Journal of Peace Research, vol. 42, no. 3, 2005, pp. 329-346.

[10] UN News, FEATURE SERIES: What Is UN Peacebuilding and Its Role in Preventing Conflicts? July 27, 2016.

[11] For example, limits of peacebuilding theory is examined in the following: Steinberg, Gerald M., The Limits of Peacebuilding Theory, Routledge Handbook of Peacebuilding, Routledge, 2013.

[12] M. Adrian, "Environmental conflict between refugee and hos communities," Journal of Peace Research, vol. 42, no. 3, 2005, pp. 329-346.

[13] UNEP, Environmental Cooperation for Peacebuilding Programme, 2016.

[14] F. Itay, "Ambiguity in transboundary environmental dispute resolution: The Israeli-Jordanian water agreement," Journal of Peace Research, vol. 45 , no. 1,2008 , pp. $91-110$

[15] F. Aleena, The Impact of Syrian Refugees on Jordan's Water Resources and Water Management Planning, Columbia University Library, 2014.

[16] UNEP, From Conflict to Peacebuilding: The Role of Natural Resources and the Environment, 2009.

[17] In Lebanon, International donors conducted environmental assessment after the influx of Syrian refugees, Lebanon Environmental Assessment of the Syrian Conflict \& Priority Interventions, 2014.

[18] UN-DESA Division for Sustainable Development Goals web site.

[19] World Vision stated on social cohesion that "Humanitarians have yet to (as an industry) articulate or agree on what social cohesion is, how best to measure it, what causes it or how it impacts communities in conflict-affected urban emergencies, such as in the Syrian regional context. This will require consulting academic research to leverage theoretical and methodological good practices and will also require consulting good practices and good processes from additional geographic contexts."

[20] UNDP, Conflict and Development Analysis, 2016.

[21] UNDP, Municipal Needs Assessment Report: Mitigating the Impact of the Syrian Refugee Crisis on Jordanian Vulnerable Host Communities, 2014.

[22] Japan International Cooperation Agency and Kokusai Kogyo, "Data collection survey on waste management in northern region accepting Syrian refugees in the Hashemite kingdom of Jordan, 2016," Japan International Cooperation Agency and Kokusai Kogyo, 2017.

[23] A Jordan Response Platform for the Syria Crisis Web Site.

[24] Ministry of Planning and International Cooperation, Jordan Response Plan for the Syria Crisis 2018-2020, 2018.

[25] UNDP Jordan office, UNDP Jordan Enhances Health and Environmental Conditions of Al-kaidar Landfill, Aug 22, 2017.

[26] Refugees Operational Data Portal by UNHCR, Total Persons of Concern, 2018.

[27] UNHCR, Registered Syrians in Jordan 15 August 2018.

[28] Oxfam web site. [Online]. Available: https://oxf.am/2FKOfrn

[29] UNHCR. (2018). Syrian Refugees in Jordan - by Locality End of March 2018. [Online]. Available: https://data2.unhcr.org/es/documents/download/63034

[30] K. Silpa et al., What a Waste 2.0: A Global Snapshot of Solid Waste Management to 2050, 2018.

[31] UNDP, Launch of New Infrastructure at Al-Ekeider Landfill in Irbid Apr 7, 2017, 2017.

[32] Oxfam, Trash Talk: turning waste into work in Jordan's Za'atari refugee camp, Oxfam Discussion Paper, 2017.

[33] Disaster Waste Recovery, Guidelines for Implementing Cash-for-Work Projects in the Waste Management Sector, 2017.

[34] UNDP, Guidance Note on Municipal Solid Waste Management in Crisis and Post-Crisis Setting, 2016.

[35] S. Motasem et al., "Solid waste composition analysis and recycling evaluation: Zaatari Syrian refugees camp, Jordan," Waste Management, vol. 61, March 2017.

[36] UNDP, Supporting Nepal to Build Back Better, 2015.

[37] Mercy Corps, Guide to Cash-for-Work Programming, 2007.

[38] UNEP, OCHA, Disaster Waste Management Guidelines, 2011.

[39] A. Ashraf and E. Chukwunonye, "Framework for management of post-conflict waste in Libya," European Scientific Journal, 2017.

[40] J. Patrícia and S. Ricardo, Employment and Household Welfare, Routledge Handbook of Peacebuilding, Routledge, 2013.

[41] L. S. Yong and O. Alpaslan, Local Ownership in International Peacebuilding: Key Theoretical and Practical Issues, Routledge, 2015.

[42] JICA, "JICA strategy paper on solid waste management," 2015, Sakurai, Kunitoshi, Journal of the Japan Society of Material Cycles and Waste Management, vol. 11, 2000, pp. 142-151.

[43] British Embassy in Amman, Social Cohesion in Host Communities in Northern Jordan, 2015.

[44] JICA, Thematic Guidelines on Solid Waste Management, 2009.

[45] S. Lisa, Conflict Assessment and Peacebuilding Planning: Toward a Participatory Approach to Human Security, Kumarian Press, 2013.

[46] Lewis, Miranda, Asylum: Understanding Public Attitudes, 2005.

[47] Martin illustrated participatory environmental management processes in refugee hosting communities, Martin, Adrian, Environmental Conflict between Refugee and Host Communities, Journal of Peace Research, vol. 42, no. 3, 2005, pp. 329-346.

[48] T. A. K. Al-Qdah and L. Marie, "T. A. K. Al-Qdah and Marie Lacroix adopted participatory, bottom-up, and human rights centered approach as named Participatory Rapid Appraisal (PRA) for needs assessment," Syrian Refugees in Jordan: Social Workers Use a Participatory Rapid Appraisal (PRA) Methodology for Needs Assessment, Human Rights and Community Development.

[49] A. Mohammad, "Solid waste management in Jordan," International Journal of Academic Research in Business and Social Sciences, vol. 4, no. $11,2014$.

[50] Jordan Green Building Council, Your Guide to Solid Waste Management in Jordan, 2015.

[51] The Population Division of the Department of Economic and Social Affairs of the United Nations, 2018 Revision of World Urbanization Prospects-Jordan, 2018.

[52] M. Vaccari, "Managing solid waste under crisis: the case of Syrian refugees in northern Jordan," presented at Sixteenth International Waste Management and Landfill Symposium, 2017.

[53] Japan International Cooperation Agency, Press Releases; Signing of Grant Agreement with Jordan: Strengthening Waste Management Capacity to Contribute to Improvements in Sanitation and the Living 
Environment in the North Where There Are Many Refugees, May 2 2018.

[54] West Asia-North Africa Institute, Syrian Refugees and Social Cohesion in Jordan, 2018.

[55] N. Narongsak, "Narongsak Noosorn stated that the community involvement and the problem solving process through participatory management of waste disposal is effective for solving problems,' Participatory Management of Waste Disposal, 2005, vol. 36, no. 3, pp $797-800$

[56] International Republican Institute, Survey of Jordan Public Opinion, 2015.

[57] Based on an interview with child waste picker in August, 2017 at Al-Huseyneyat Landfill.

[58] Mercy Corps, Analysis of Host Community-Refugee Tensions in Mafraq, Jordan, 2012.
[59] Based on an interview with a staff of international organization in August, 2017 in Amman.

[60] IOM, World Migration Report 2018, 2018.

Tsuyoshi Yamamoto graduated from the Faculty of Social Science of Waseda University, Japan in 2004, and obtained the master degree from the Graduate School of Asia-Pacific Studies of Waseda University in 2006. His major field of study is development study, international relations and peace study. He has worked for Japan International Cooperation Agency in 12 years; for example, Central Asia and the Caucasus division 2009-2011; Afghanistan office 2011-2013; Europe division 2013-2015; His current position is deputy director of environmental management team of Global Environment Department since 2015. 